\title{
7. Britain must defy the European Court of Human Rights on prisoner voting as Strasbourg is exceeding its authority
}

\section{David Davis}

In 2011 the British House of Commons was the scene of a robust debate on prisoner voting rights. By a majority of more than 200, MPs from both sides of the political spectrum voted in favour of the current United Kingdom ('UK') law that convicted prisoners are not eligible to be on the electoral roll. This ban has been in place for almost 150 years, since the passing of the Forfeiture Act 1870. Since that time no fewer than four Representation of the People Acts - in 1918, 1969, 1983 and 2000 have, either explicitly or implicitly, forbidden prisoners to vote while serving their sentence.

In the Representation of the People Act 2000 the law was amended to allow prisoners on remand to vote. The reason given was that prisoners on remand have been charged with an offence but not convicted of it, and as such should be treated as innocent until proven guilty. However, Parliament reaffirmed its position that convicted prisoners should be ineligible to vote for the duration of their sentence. Regrettably, these multiple, emphatic statements of the will of Parliament have not prevented the European Court of Human Rights ('ECtHR') from declaring that the UK's prohibition on prisoner voting is unlawful. It is submitted that the UK Government should defy the ECtHR on this issue because, by declaring the UK legislation incompatible with the European Convention on Human Rights ('ECHR'), it has exceeded its authority.

Section I of this chapter contains a brief discussion of the judgments of the ECtHR related to the UK prohibition on prisoner voting. In section II the case is made that the Court overstepped its legitimate authority when it declared the UK legislation to be in breach of the Convention. Section 
III considers the future development of the relationship between the ECtHR and the UK in light of this collision on voting rights for prisoners.

\section{ECtHR CASE LAW ON PRISONER VOTING: HIRST, GREENS AND SCOPPOLA}

In 2005, John Hirst successfully sued the British Government before the ECtHR for denying him the right to vote. Hirst, whilst out of prison on parole in 1979, killed his landlady with an axe. He then made himself a cup of coffee in the kitchen whilst she lay dying in the lounge. Despite this the ECtHR held that the law banning convicted prisoners from voting was in breach of Britain's obligation to hold free elections at reasonable intervals by secret ballot. ${ }^{1}$ This obligation was laid down in Article 3 of Protocol No. 1 ECHR. According to the ECtHR the restriction on voting rights for prisoners falls outside the UK's margin of appreciation because it is general, automatic and indiscriminate. ${ }^{2}$

In November 2010 convicted rapist Robert Greens and another inmate identified only as 'MT', won a further prisoners' voting rights case in Strasbourg against the UK. ${ }^{3}$ They complained that as convicted prisoners they had been prevented from voting in elections to the European Parliament and in the 2010 UK general election. The ECtHR found that the UK had again violated Article 3 of Protocol No. 1 ECHR. It expressed the view that this violation was the direct result of the failure by the UK Government to introduce measures to comply with the Court's 2005 Hirst judgment. ${ }^{4}$ Therefore, the ECtHR gave the UK six months to introduce legislation to remove the existing prohibition causing the violation. ${ }^{5}$

On 22 May 2012 the ECtHR handed down its judgment in the case of Scoppola v. Italy in which the applicant challenged the fact that he had been disenfranchised as a result of his conviction. ${ }^{6}$ This case was particularly interesting not only because Italy's rules on prisoner voting

\footnotetext{
1 Hirst v. The United Kingdom (No. 2) App no 74025/01 (ECHR 6 October

2 Ibid, para 82.

3 Greens and MT v. The United Kingdom App nos 60041/08 and 60054/08 (ECHR 23 November 2010).

4 Ibid, para 110.

5 Ibid, para 115.

6 Scoppola v. Italy (No.3) App no 126/05 (ECHR 22 May 2012).
} 2005). 
are similar to Britain's, but also because the UK intervened in the case with Attorney General Dominic Grieve personally addressing the Court. ${ }^{7}$ Grieve rightly argued that member States are entitled to a wide margin of appreciation with regard to prisoner voting rights; that each State should be free to adopt its own rules in keeping with its own social policy; and, as such, that the ECtHR should revisit its decision in Hirst.

The Court, however, did no such thing. It reaffirmed the principles set out in Hirst, in particular that a blanket ban irrespective of the length of sentence and the gravity of the offence is contrary to Article 3 of Protocol No. 1 ECHR. 8 The Italian legislation survived this test as it is only applied in connection with certain offences, while having regard to the offender's personal situation, including mitigating and aggravating circumstances. ${ }^{9}$

\section{WHY THE COURT OVERREACHED BY DECLARING THE UK PROHIBITION ON PRISONER VOTING INCOMPATIBLE WITH THE ECHR}

Of course, the UK Government should not defy Strasbourg judgments regarding serious breaches of human rights, such as concerns that a deportee may be tortured. Such cases are precisely what the Court was set up to do. Its conclusions in such cases ought to be respected by Britain and other member States in accordance with their obligations under the ECHR. However, in recent years the Court seems to have forgotten that its job is to apply the principles of the Convention as originally intended by those who signed it - nothing more and nothing less. The Vienna Convention on the Law of Treaties requires that international treaties be interpreted as their drafters intended. ${ }^{10}$ Ignoring this injunction, the Court has defined the European Convention as a 'living instrument' to allow it to expand its influence as the judges see fit. ${ }^{11}$

Article 3 of Protocol No. 1 ECHR is a case in point. This provision requires States to hold free elections at reasonable intervals by secret

\footnotetext{
7 Ibid, paras $75-80$.

8 Ibid, para 96.

9 Ibid, para 106.

10 See Article 32 in particular. Vienna Convention on the Law of Treaties (23 May 1969, 1155 UNTS 331. Entered into force on 27 January 1980).

11 See e.g. Tyrer v. The United Kingdom App no 5856/72 (ECHR 25 April 1987) para 31.
} 
ballot, but nowhere does it grant universal suffrage. The Article is different from all the other clauses in the ECHR and it is clear that it was meant to guarantee a proper functioning of the democratic process and not to grant individual rights. This was reflected in the Commission's early case law, ${ }^{12}$ until the Court changed course in Mathieu-Mohin. ${ }^{13}$ Therefore, reading an individual right to vote, especially one based on universal suffrage, into Article 3 of Protocol No. 1 ECHR is stretching this clause beyond its proper and intended meaning. The dissenting judges in Hirst took a similar view. ${ }^{14}$

According to the ECtHR's own case law, if there is consensus among member States on how to deal with a particular issue, then individual States enjoy only a small margin of appreciation. ${ }^{15}$ On the other hand, if such consensus is lacking, States enjoy a wide margin of appreciation. As the Court admitted in Hirst, there are at least 12 States other than the UK that deny all convicted prisoners the right to vote. ${ }^{16}$ If the ECtHR would have taken its own case law seriously, it would have concluded that, therefore, the UK is entitled to a wide margin of appreciation on prisoner voting. Instead the ECtHR ignored its own case law and decided that the absence of consensus should not be determinative of the issue. ${ }^{17}$

Finally, in Greens and MT v. The UK the Court ordered the UK to legislate to enable prisoners the vote within six months. ${ }^{18}$ Under the ECHR it is up to the States themselves to give effect to the Court's decisions under the supervision of the Committee of Ministers. ${ }^{19}$ Nowhere does the treaty allow the Court to issue such writs of mandamus subjecting States to a strict timeframe for the amendment of their

12 X v. Germany App no 530/59 (4 January 1960) Collection 2; and $X v$. Belgium App no 1028/61 (18 September 1961) Collection 6.

13 Mathieu-Mohin and Clerfayt v. Belgium App no 9267/81 (ECHR 2 March 1987).

14 Hirst, supra n 1, see joint dissenting opinion of Judges Wildhaber, Cost, Lorenzen, Kolver and Jebens.

15 See for example Handyside v. The United Kingdom App no 5493/72 (ECHR 7 December 1976) paras 48 and 49. See also in this volume Tom Zwart, 'More human rights than Court: why the legitimacy of the European Court of Human Rights is in need of repair and how it can be done' chapter 8; and Kanstantsin Dzehtsiarou, 'Interaction between the European Court of Human Rights and member States: European consensus, advisory opinions and the question of legitimacy' chapter 11 .

16 Hirst, supra n 1, para 81.

17 Ibid.

18 Greens, supra n 3, para 115.

19 Article 46 ECHR. 
national law. By tying Britain to this timetable the Court has clearly acted ultra vires. As a result, the UK is now in a situation where the Court is trying to impose its judgments, which would have astonished those who originally signed the Convention. By taking this approach, Strasbourg risks undermining its own authority.

\section{CONSEQUENCES OF THE CURRENT STAND-OFF FOR UK-ECtHR RELATIONS}

On a visit to Britain in 1997, the former German President Roman Herzog was asked what would happen if there was a conflict between the ECtHR and the German Constitutional Court. The President replied: 'I think the German people would support their own court.' Regarding prisoner franchise, it is proposed that equally, the British people will support their own Parliament.

If the UK Government does what it is told and presents a Bill before Parliament that proposes enabling prisoners to vote, the MPs would almost certainly reject that Bill. Not only is this rather ironic given the fact that Article 3 of Protocol No. 1 ECHR purports to guarantee the proper functioning of the democratic process, it also means that a legitimate and properly elected national parliament effectively checkmates the ECtHR when its judges act outside the limits of their proper authority. Should the Court insist on expanding its influence, Strasbourg judges will find themselves more frequently in direct opposition to national courts and parliaments. Democratic parliaments across Europe will be forced, with increasing regularity, to choose between the will of their people and the views of foreign judges. If Britain stands up to Strasbourg over prisoner franchise, it will be noticed beyond our borders. Serious concerns about the Court also exist in countries such as the Netherlands and Germany. ${ }^{20}$ By attempting to back Britain into a corner, Strasbourg risks seeing defiance of its judgments become the rule rather than the exception.

There are those who say that the UK has accepted the jurisdiction of the Strasbourg Court and must now obey all its decisions. This is, however, not the case. Britain cannot be forced to grant prisoners the vote or to pay compensation to prisoners who sue the Government over this

20 For a discussion on the criticisms in the Netherlands see Janneke Gerards and Ashley Terlouw, 'Solutions for the European Court of Human Rights: The Amicus Curiae Project' chapter 14. 
issue. The Court does not have the power to fine Britain for noncompliance with its judgments. Nor would the UK be expelled from the Council of Europe for non-compliance as some claim. The Council, which is in charge of the Strasbourg Court, has failed to expel Bulgaria for cases of fatal police brutality, Moldova for torture in prisons and Russia for atrocities committed in Chechnya, so it is unlikely for Britain to be expelled for not putting a ballot box in Wormwood Scrubs at the next local elections. ${ }^{21}$ If we say 'sorry, but no' to Strasbourg over prisoner voting, the matter will simply remain on a long list of unenforced judgments.

The tragedy of all this is that by forcing the issue on this marginal interpretation of a 'right' in Article 3 of Protocol No. 1 ECHR, the Court is undermining its own authority in the many important cases where it is in dispute with member States over serious and real human rights violations.

It is the duty of parliamentarians to protect Britain's ancient rights and freedoms. But while we must defend those rights fearlessly, we should never confuse those universal freedoms with the minor social policy issue of prisoner voting. Of course prisoners have rights - to be reasonably fed, clothed and housed - but they do not have all those rights that free British citizens enjoy. When a person commits a crime that is sufficiently serious to warrant imprisonment, the person sacrifices their liberty, freedom of association and their right to vote. When we vote in a government we choose a group of men and women to make laws on our behalf. Convicted prisoners should have no say in this; those who break the law cannot make the law.

We do not dispute the right of the Strasbourg Court to curb government excesses within the constraints of the Convention that Britain has signed. However, in attempting to overrule the British law on prisoner voting, Strasbourg judges have exceeded the limits of their proper authority. If the Court does not reflect the views of member States of the Council of Europe or if it infringes States' constitutional rights, conflict will ensue.

21 See, for example, Nachova and Others v. Bulgaria App nos 43577/98 and 43579/98 (ECHR Grand Chamber 6 July 2005); Ciorap v. Moldova (no. 2) App no 7481/06 (ECHR 20 October 2010); Pădureț v. Moldova App no 33134/03 (ECHR 5 April 2010); Bazorkina v. Russia App no 69481/01 (ECHR 11 December 2006); and Isayeva v. Russia App no 57950/00 (ECHR 6 July 2005). 